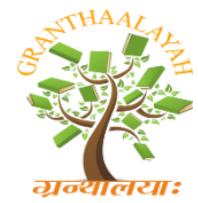
\author{
GRANTHAALAYAH \\ A knowledge Repository
}

INTERNATIONAL JOURNAL OF RESEARCH -

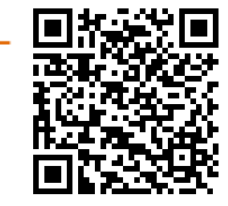

Science

\title{
A CLINICAL STUDY TO EVALUATE THE EFFICACY OF SELECTED TRADITIONAL HAIR PACK FOR DANDRUFF
}

\author{
M.P.N.Pramodani ${ }^{* 1}$, W.J. Wickramarachchi ${ }^{2}$ \\ ${ }^{*} 1,2$ Department of Cikitsa, Gampaha Wickramarachchi Ayurveda Institute, University of \\ Kelaniya, Yakkala, Sri Lanka
}

DOI: https://doi.org/10.29121/granthaalayah.v5.i1.2017.1685

\begin{abstract}
Darunaka is a disease concerned to hair root which can be correlate with Dandruff, which is the most common cause for hair loss. It is more of a social problem and affects aesthetic value as a person with Dandruff is quite likely to feel down on the social ring. Acharya Sushruta has mentioned Darunaka under Kshudraroga's with symptoms like rukshata, kandu, twak sphutana etc. Dandruff can occur due to air pollution, water pollution, changed life style, irregular daily regimen, poor hygiene and immune system, sweating, mental stress etc which can lead to several bacterial and fungal infections. It is a common scalp disorder affecting almost half of the population at the pre-pubertal age and of any gender and ethnicity. No population in any geographical region would have passed through freely without being affected by dandruff at some stage in their life. Shiroabhyanga, Nasya, Shirodhara, Shirobasti,Shirolepa and Siravyadha is the line of treatment for Darunaka in the classics. In traditional medicine paste of leaves of Elaeocarpus serratus and Psidium guajava are using for thousand years as a home remedy for dandruff in Sri Lanka .In spite of the present medical solutions Dandruff relapses quite often. A permanent and holistic solution is the need of the hour. Hence, this work is intended to study the efficacy of Elaeocarpus serratus and Psidium guajava leaves paste for dandruff. Thirty patients were selected; advised to apply the paste covering whole scalp area for one hour and rinse it, for a period of one month every alternative day. Signs and symptoms were assessed by using grading system and observed the significant reduction of symptoms. Considering the total treatment assessment more than $40 \%$ patients gain complete remission and $30 \%$ got marked improvement. No adverse reaction reported in this study period. It is concluded that Elaeocarpus serratus and Psidium guajava leaves paste is very beneficial to manage Dandruff.
\end{abstract}

Keywords: Darunaka; Dandruff; Elaeocarpus Serratus; Psidium Guajava.

Cite This Article: M.P.N.Pramodani, and W.J. Wickramarachchi. (2017). "A CLINICAL STUDY TO EVALUATE THE EFFICACY OF SELECTED TRADITIONAL HAIR PACK FOR DANDRUFF." International Journal of Research - Granthaalayah, 5(1), 12-21. https://doi.org/10.29121/granthaalayah.v5.i1.2017.1685. 


\section{Introduction}

Dandruff (also referred as "Pityriasis simplex") is a common embarrassing disorder, which affects $5 \%$ of the global population. Dandruff mostly occurs after puberty (between ages of 20 and 30 years), and affects males more than females. ${ }^{[1]}$

Dandruff is characterized by scaling of the scalp, and is frequently associated with seborrhea ${ }^{[2]}$, and seborrhea is the precursor of seborrheic dermatitis. ${ }^{[3]}$

The yeast, Pityrosporum ovale is the causative microorganism of dandruff. Pityrosporum ovale feed on the dermal lipids and proteins and facilitates lipase activity, which releases pro inflammatory free fatty acids (FFAs) causing dermal inflammation and tissue damage. The lipase activity indicates that in addition to hypersensitivity, Pityrosporum ovalereleases toxic chemicals, which contribute to the development of a fungal infection. ${ }^{[4]}$

Currently available treatment options for the management of dandruff include therapeutic use of zinc pyrithione, salicylic acid, imidazole derivatives, glycolic acid, steroids, sulphur and tar derivatives. ${ }^{[5]}$ However, these agents have certain limitations, either due to poor clinical efficacy or due to the compliance issues. Furthermore, these drugs are unable to prevent recurrence, which is the commonest problem.

With regard of available description of the disease Dandruff can be correlate with the Darunaka due to Equivalence of signs and symptoms and the pathophysiology of two diseases.

According to vagbhata ${ }^{[6]}$ and sharangadara ${ }^{[7]}$ the Darunaka is a kapalagata roga but sushruta [8] and other acharyas explained this disease under kshudra rogas, Dandruff is an irritative disease of the scalp in which shedding of dead tissue from the scalp with itching sensation is the cardinal feature. As per Ayurveda classics Rejection of kesha taila, Improper cleaning, sleeping during day time, Night vigil, Exposure to dust, hot weather, etc are causative factors for Darunaka with symptoms3 like Kandu, Rukshata, Twak sphutana, Kesha Chyuti, etc due to the vitiation of Vata and Kapha dosha ${ }^{[8,9]}$ Till now there is no definite cause and solution for this disease. So there is a need to find a safe and effective remedy in the treatment of Darunaka.

Shiroabhyanga, Nasya, Shirodhara, Shirobasti, Shirolepa and Siravyadha is the line of treatment for Darunaka in the classics. In traditional medicine paste of leaves of Elaeocarpus serratus and Psidium guajava are using for thousand years as a home remedy for dandruff in Sri Lanka. Hence, this work is intended to study the efficacy of Elaeocarpus serratus and Psidium guajava leaves paste for dandruff.

\section{Aims and Objectives}

To assess the effectiveness of Elaeocarpus serratus and Psidium guajava leaves paste for dandruff 


\section{Materials and Methods}

\section{Inclusion Criteria}

Thirty patients attending for clinics in Gampaha Wickramarachchi Ayurveda Hospital, Yakkala, Sri Lanka fulfilling the criteria of the disease Dandruff was selected randomly irrespective of their age, gender, religion etc.

\section{Exclusion Criteria}

Patients with concomitant severe scalp infection, Patients with history of hypersensitivity, Patients with preexisting severe systemic disease necessitating in long-term medication were excluded.

Before the treatment, the procedure was explained to the patients and got their written consent. Patients were examined and recorded their history in the Performa which prepared including all the necessary aspects of Ayurveda and modern medical science.

They were advised to apply the paste covering whole scalp area in day time for one hour and rinse it, for a period of one month every alternative day. All the patients were asked to adhere to the trialed paste only as the treatment for dandruff, and no other medicated topical application was allowed.

\section{Assessment Criteria}

The clinical condition was assessed before and after treatment period and after follow up period on the basis of relief of the signs and symptoms.

\section{Subjective Criteria}

Signs and associated symptoms were assessed by using grading system given such as severe: 3 , moderate: 2 , mild: 1 and cured: 0 .
1. Scaling
2. Pruritus
3. Tight feeling
4. Erythema
5. Hair fall
6. Dry scalp

\section{Total Treatment assessment}

- Complete Remission : $100 \%$ relief

- Marked Improvement : More than 75\% improvement

- Moderate Improvement : $50 \%$ to $75 \%$ improvement

- Mild Improvement : $25 \%$ to $49 \%$ improvement

- Unchanged : Less than $25 \%$ reduction

\section{Follow up}

Patients were followed for one month after the treatment. 


\section{Results and Discussions}

Table 1: Distribution of patients by Gender

\begin{tabular}{|l|l|l|}
\hline Gender & No of Patients & Percentage \\
\hline Male & 14 & $46.66 \%$ \\
\hline Female & 16 & $53.33 \%$ \\
\hline
\end{tabular}

Among the Thirty patients, 14 patients (46.66\%) were male and 16 patients $(53.33 \%)$ were female. But the previous researches show that the males are more prone to Dandruff than the females.They shows one out of three men is affected by the Dandruff associated with testosterone, the principle male sex hormone. Male scalps produce 50\% more sebum than female scalps. Whilst it's normal to produce sebum, too much on the scalp may act as a breeding ground for dandruff causing microbes.Men also have a much weaker scalp barrier than women, which makes them more prone to dandruff. A weakened scalp barrier means that men lose moisture a lot quicker than women do, putting them at a higher risk of dry scalp and itchiness.

In present study most of patients were female it may be because they are most concerning about the problem and move to the treatments.

Table 2: Distribution of patients by Age

\begin{tabular}{|l|l|l|}
\hline Age (years) & No of Patients & Percentage \\
\hline Below 20 & 06 & $20.00 \%$ \\
\hline $20-30$ & 12 & $40.00 \%$ \\
\hline $31-40$ & 10 & $33.33 \%$ \\
\hline $41-50$ & 02 & $6.66 \%$ \\
\hline
\end{tabular}

When selecting representative sample, the patient's age was not considered. Maximum number of patients represents the 20-30 Age groups. Dandruff is also more common in young adulthood through to middle age.

By analyzing ordinal type scale of measurements, below table would be explained median and mode values to have brief understanding about relevant central tendency measurements.

Table 3: Descriptive statistics for Independent variables

\begin{tabular}{|l|l|l|l|l|}
\hline & Median & Mode & Minimum & Maximum \\
\hline Scaling- Pre & 2.00 & 2 & 1 & 3 \\
Scaling- Post & .00 & 0 & 0 & 3 \\
Pruritus- Pre & 2.00 & 2 & 0 & 3 \\
Pruritus- Post & .00 & 0 & 0 & 2 \\
Tight feeling- Pre & 1.00 & 0 & 0 & 3 \\
Tightr feeling- & .00 & 0 & 0 & 1 \\
Postrat & & & &
\end{tabular}




\begin{tabular}{|l|l|l|l|l|} 
Erythema- Pre & 1.00 & 0 & 0 & 3 \\
Erythema- Post & .00 & 0 & 0 & 1 \\
Hair fall- Pre & 2.00 & 3 & 0 & 3 \\
Hair fall- Post & .00 & 0 & 0 & 2 \\
Dry scalp- Pre & 1.00 & 0 & 0 & 3 \\
Dry scalp- Post & .00 & 0 & 0 & 1 \\
\hline
\end{tabular}

*0-None, 1-Mild, 2-Moderate, 3-Severe

Scaling \& Pruritus diagnoses had moderate level diagnostic symptoms when patients were suffered in the clinic. After treatment and recovery stage passed, those symptoms were dissolved as hundred percent. Most common factor was hair fall symptom for that diagnosis (mode value exhibited as severe level influence), but sample patients were overcome such symptom after having correct medications.

Table 4 : Tests of Normality

\begin{tabular}{|l|l|l|l|l|l|l|}
\hline \multirow{2}{*}{} & \multicolumn{3}{|l|}{ Kolmogorov-Smirnov ${ }^{\mathrm{a}}$} & \multicolumn{3}{l|}{ Shapiro-Wilk } \\
\cline { 2 - 7 } & Statistic & $\mathrm{df}$ & Sig. & Statistic & df & Sig. \\
\hline Scaling- Pre & .268 & 30 & .000 & .790 & 30 & .000 \\
Pruritus- Pre & .253 & 30 & .000 & .848 & 30 & .001 \\
Tight feeling- & .258 & 30 & .000 & .806 & 30 & .000 \\
Pre & & & & & \\
Erythema- Pre & .291 & 30 & .000 & .794 & 30 & .000 \\
Hair fall- Pre & .201 & 30 & .003 & .851 & 30 & .001 \\
Dry scalp- Pre & .247 & 30 & .000 & .791 & 30 & .000 \\
\hline
\end{tabular}

a. Lilliefors Significance Correction

H0: respective variable satisfy normality conditions/ requirements

Ha: Given variable is not satisfy normality conditions

By saying above hypotheses, all six types of pre staged symptoms were significant at ninety five percent confidence limit which indicated that, all pre- staged variables were not satisfy mathematical based normality requirements. So, Wilcoxon signed rank test was used to measure the effective of the treatment as below.

According to Wilcoxon signed- ranks method;

H0: Two related variables have equal median values vs. Ha: Two related variables have different median values

When considering post treatments to pre stage diagnoses, scaling had fifteen value for mean rank value by contributing twenty nine supportive proofs. 
Table 5: Wilcoxon signed- ranks test

\begin{tabular}{|c|c|c|c|c|}
\hline & & $\mathrm{N}$ & Mean Rank & Sum of Ranks \\
\hline \multicolumn{2}{|c|}{ Scaling- Post - Scaling- Negative Ranks } & $29^{\mathrm{a}}$ & 15.00 & 435.00 \\
\hline \multirow[t]{3}{*}{ Pre } & Positive Ranks & $0^{\mathrm{b}}$ & .00 & .00 \\
\hline & Ties & $1^{\mathrm{c}}$ & & \\
\hline & Total & 30 & & \\
\hline \multirow{4}{*}{$\begin{array}{l}\text { Pruritus- Post } \\
\text { Pruritus- Pre }\end{array}$} & - Negative Ranks & $25^{\mathrm{d}}$ & 13.00 & 325.00 \\
\hline & Positive Ranks & $0^{\mathrm{e}}$ & .00 & .00 \\
\hline & Ties & $5^{\mathrm{f}}$ & & \\
\hline & Total & 30 & & \\
\hline \multirow{4}{*}{$\begin{array}{l}\text { Tight feeling- Post } \\
\text { Tight feeling-Pre }\end{array}$} & - Negative Ranks & $16^{g}$ & 8.50 & 136.00 \\
\hline & Positive Ranks & $0^{\mathrm{h}}$ & .00 & .00 \\
\hline & Ties & $14^{\mathrm{i}}$ & & \\
\hline & Total & 30 & & \\
\hline \multirow{4}{*}{$\begin{array}{l}\text { Erythema- } \\
\text { Erythema- Pre }\end{array}$} & - Negative Ranks & $16^{\mathrm{j}}$ & 9.34 & 149.50 \\
\hline & Positive Ranks & $1^{\mathrm{k}}$ & 3.50 & 3.50 \\
\hline & Ties & $13^{1}$ & & \\
\hline & Total & 30 & & \\
\hline \multirow{4}{*}{$\begin{array}{l}\text { Hair fall- Post - Ha } \\
\text { fall- Pre }\end{array}$} & ir Negative Ranks & $23^{\mathrm{m}}$ & 12.76 & 293.50 \\
\hline & Positive Ranks & $1^{\mathrm{n}}$ & 6.50 & 6.50 \\
\hline & Ties & $6^{\circ}$ & & \\
\hline & Total & 30 & & \\
\hline \multirow{4}{*}{$\begin{array}{l}\text { Dry scalp- Post - Di } \\
\text { scalp- Pre }\end{array}$} & y Negative Ranks & $17^{\mathrm{p}}$ & 9.68 & 164.50 \\
\hline & Positive Ranks & $1^{\mathrm{q}}$ & 6.50 & 6.50 \\
\hline & Ties & $12^{\mathrm{r}}$ & & \\
\hline & Total & 30 & & \\
\hline
\end{tabular}

As better representative evidence was expected high sample proportion for negative ranks value rather than positive rank number of observation and ties observation. By considering the higher mean rank values and higher sum of rank values major frequencies diagnosis resolvement symptoms could be observerable For scaling, Pruritus and hair fall respectively. 
Table 6: Wilcoxon signed- ranks test statistics

\begin{tabular}{|c|c|c|c|c|c|c|}
\hline & $\begin{array}{l}\text { Scaling- Post } \\
\text { - Scaling- Pre }\end{array}$ & $\begin{array}{lr}\text { Pruritus- Post } \\
- & \text { Pruritus- } \\
\text { Pre } & \end{array}$ & $\begin{array}{l}\text { Tight feeling- } \\
\text { Post - Tight } \\
\text { feeling- Pre }\end{array}$ & $\begin{array}{l}\text { Erythema- } \\
\text { Post } \\
\text { Erythema- } \\
\text { Pre }\end{array}$ & $\mid \begin{array}{ll}\text { Hair } \quad \text { fall- } \\
\text { Post - } & \text { Hair } \\
\text { fall- Pre } & \end{array}$ & $\begin{array}{l}\text { Dry scalp- } \\
\text { Post - Dry } \\
\text { scalp- Pre }\end{array}$ \\
\hline Z & $-4.789^{a}$ & $-4.437^{a}$ & $-3.581^{a}$ & $-3.534^{\mathrm{a}}$ & $-4.178^{a}$ & $-3.568^{\mathrm{a}}$ \\
\hline $\begin{array}{l}\text { Asymp. Sig. } \\
(2-\text { tailed) }\end{array}$ & .000 & .000 & .000 & .000 & .000 & .000 \\
\hline
\end{tabular}

a. Based on positive ranks.

b. Wilcoxon Signed Ranks Test

Above table was exhibited that all six factors were significant at five percent error level which described that all symptoms had different median values for pre stage and post stage categories respective. It persuades that selected treatment able to reduce all the symptoms of Dandruff.

Table 7: Valid percentages table

\begin{tabular}{|c|c|c|c|c|}
\hline \\
\hline Symptom & None & Mild & Moderate & Severe \\
\hline Scaling-Pre & $*$ & 13.3 & 50 & 36.7 \\
\hline Scaling- Post & 76.7 & 10 & 10 & 3.3 \\
\hline Pruriturs- Pre & 132 & 167 & 10 & 30 \\
\hline Pruritus- Pre & $\frac{13.3}{72.2}$ & $\frac{16.1}{292}$ & 40 & 30 \\
\hline Pruritus- Post & 73.3 & 23.3 & 3.3 & $*$ \\
\hline Tight feeling- Pre & 43.3 & 23.3 & 16.7 & 16.7 \\
\hline $\begin{array}{l}\text { Tight feeling- } \\
\text { Post }\end{array}$ & 83.3 & 16.7 & $*$ & $*$ \\
\hline Erythema- Pre & 46.7 & 13.3 & 26.7 & 13.3 \\
\hline Erythema- Post & 86.7 & 13.3 & $*$ & $*$ \\
\hline & & & & \\
\hline Hair fall- Pre & 16.7 & 23.3 & 26.7 & 33.3 \\
\hline Hair fall- Post & 56.7 & 40 & 3.3 & $*$ \\
\hline Dry scalp- Pre & 43.3 & 33.3 & 10 & 13.3 \\
\hline Dry scalp- Post & 93.3 & 6.7 & $*$ & $*$ \\
\hline
\end{tabular}

Scaling variable had impact reduction from $36.7 \%$ for severe stage to $76.7 \%$ as $100 \%$ cured. When analyzing the above percentage value it can be observed that after the treatment majority of patients are move to reduction stage of disease. 
Table 8: Total Treatment Assessment

\begin{tabular}{|l|l|l|}
\hline $\begin{array}{l}\text { Total Treatment } \\
\text { Assessment }\end{array}$ & $\begin{array}{l}\text { No. of } \\
\text { patients }\end{array}$ & Percentage \\
\hline Complete Remission & 12 & $40 \%$ \\
\hline Marked Improvement & 9 & $30 \%$ \\
\hline $\begin{array}{l}\text { Moderate } \\
\text { Improvement }\end{array}$ & 7 & $23 \%$ \\
\hline Mild Improvement & 2 & $07 \%$ \\
\hline Unchanged & 0 & $0 \%$ \\
\hline
\end{tabular}

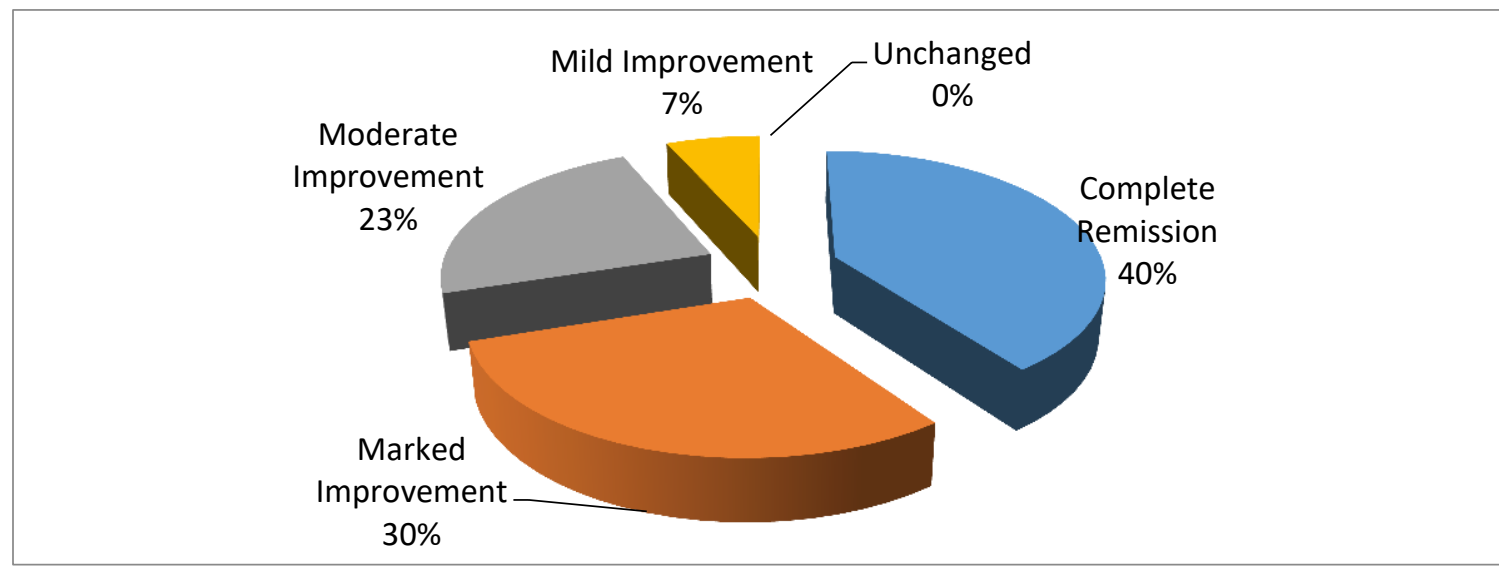

Figure 1: Total Treatment Assessment

Figure 1 illustrated that there was decreasing percentage values occurred through total treatment assessment segment wise respectively. It indicates that total treatment assessment characteristics had ranked pattern. So, there was higher percentage value $(70 \%)$ obtained by combining complete remission, marked improvement portions. It means $70 \%$ of patients got more than $75 \%$ reduction of the disease after the treatment period.

\section{Discussion}

A person's entire body surface continuously sheds dead skin cells and the skin itself sheds every twenty-four days. Dandruff, the shedding of dead skin cells from the scalp at an excessive rate, is the result of the normal growing process of the skin cells of the scalp. Dandruff is a global phenomenon and can cause social or self-esteem problem.

Dandruff may be caused by several different factors, but the exact underlying cause of dandruff is unknown (at least not agreed upon by the medical fraternity). Dandruff is the visible desquamation of scalp, is the mildest manifestation of seborrheic dermatitis. Dandruff usually is a result of Pityrosporum ovale infection combined with multiple host factors. ${ }^{[10]}$

Pityrosporum organisms are linked to T-cell depression, increased sebum levels and an activation of the alternative complement pathway. The age of onset of dandruff also suggests an androgenic influence, as dandruff correlates with peak sebaceous activity. Dandruff can be seasonal, in which it is most severe during winter and mildest during summer (as ultraviolet rays 
from sunlight counteracts Pityrosporum ovale). Poor diet, poor hygiene, genetic disposition, hormonal imbalances and infections contribute to dandruff. Excessive use of hairsprays and hair gels, improper use of hair-coloring products, excessive use of electric hair curlers, dry indoor heating, tight fitting headgears or scarves, infrequent shampooing of the hair, inadequate rinsing of hair, stress, anxiety and tension worsen dandruff.

The most common symptom of dandruff is scalp scaling, and itching with scalp soreness is frequently present. Dandruff scales usually occur as small, round, white-to-gray patches on the top of the head; however, scaling can occur anywhere on the scalp. Clinically, the greyish white flakes of skin are often visible on the hair and shoulders. Unsightly flakes or scales are typically present on the scalp and trapped in the hair. Whether or not these flakes are "oily" or "dry" may provide hints about the underlying cause of the dandruff. The severity of dandruff varies from mild dandruff to exfoliative erythroderma. Seborrheic eczema is a more severe form of dandruff, which affects the skin around the eyebrows, nose, ears, face and forehead, and the typical scales are yellowish greasy with inflamed skin.

The differential diagnosis of dandruff include eczema, atopic dermatitis, candidiasis, contact dermatitis, dermatomyositis, drug eruptions, drug-induced photosensitivity, impetigo, lichensimplex, chronicus lupus erythematosus, nummular dermatitis, pemphigus, pityriasis rosea, tinea capitis, xerotic eczema, and vitamin B and/or zinc deficiency.

The aim of dandruff treatment is to reduce the number of the Pityrosporum ovale on the scalp, and the goals of therapy are to reduce morbidity and prevent complications. Dandruff is a natural process, which cannot be eliminated and dandruff can only be managed and controlled.

This study observed a significant reduction in scalp itching, inflamed scalp, hair fall and white scales of dandruff. The subjective evaluation also revealed remarkable symptomatic improvement in treatment period, dandruff was completely controlled in $40 \%$ and marked improvement in $30 \%$. The excellent antidandruff action of selected treatment might have been due to the synergistic antifungal, anti-inflammatory and local immune stimulatory actions of its ingredients, which has been well documented by various research workers.

\section{Conclusions \& Recommendations}

It can be concluded that the treatment modality, applying Elaeocarpus serratus and Psidium guajava leaves paste is effective in managing dandruff.

The excellent antidandruff action of Elaeocarpus serratus and Psidium guajava leaves paste might have been due to the synergistic antifungal, anti-inflammatory and local immuno stimulatory actions of its ingredients may success in correcting the pathophysiology of dandruff.

\section{References}

[1] Shimer A, Nathansohn N, Kaplan B, Weiss G, Newman N, Trau H. Treatment of scalp seborrheic dermatitis and psoriasis with an ointment of $40 \%$ urea and $1 \%$ bi fonazole. Int. J. Dermatol.2000; 39: 521-538. 
[2] Dawber RPR, Dide, Berker, Fennella Wojnarowska. Disorders of Hair. Champion RH, Burton JL, DA Burns DA and Breatnach SM(Editors), Rook/Wilkinson/ Eblinng Textbook of Dermatology, 6thEdition, Volume 4, 1998: pp. 2941-2942.

[3] Burton JL, Holden CA. Eczema, Lichenification and Prurigo. Champion RH, Burton JL, DA Burns DA and Breatnach SM (Editors), Rook/ Wilkinson/ Eblinng Textbook of Dermatology, 6th Edition, Volume 1, 1998; pp. 638-642.

[4] Shuster S. The aetiology of dandruff and the mode of action of therapeutic agents. Br. J. Dermatol.1984; 111: 235-242.

[5] Faergemann J, Jones JC, Hettler O, Loria Y. Pityrosporum ovale (Malassezia furfur) as the causative agent of seborrhoeic dermatitis: New treatment options. Br. J. Dermatol. 1996; 134 (Suppl. 46): 12-15

[6] Prof. Srikantha Murthy K.R , Astanga Hrdaya Samhita , Vol 3 , Reprint , Chowkhamba Krishandas Academy, Varanasi , India , 2005

[7] Nagodavithana P, Sri Sharangadhara Samhita, Samayawardhana Book Shop(PVT) LTD, Colombo, Sri Lanka, 2001.

[8] Prof. Srikantha Murthy K.R, Susruta Samhita, Vol 1,2, Chaukhambha Orientalia , Varanasi , India , 1962

[9] Sharma P.V, Caraka Samhita, Chaukhambha Orientalia, Varanasi , India , 2014

[10] McGrath J, Murphy GM. The control of seborrhoeic dermatitis and dandruff by antipityrosporal drugs.Drugs 1991; 41: 178-184.

*Corresponding author.

E-mail address: pramodani@ayu.lk 